\title{
Which Nutritional and Demographic Characteristics Affect Hopelessness in Young Adults? A Cross-Sectional Study of University Students From Turkey
}

\author{
Zeynep Uzdil' (iD , Nermin Kılıç ${ }^{1}$ iD , Aliye Özenoğlu' ${ }^{1}$ (iD
}

${ }^{1}$ Ondokuz Mayıs Üniversitesi, Sağlık Bilimleri Fakültesi, Beslenme ve Diyetetik Bölümü, Samsun, Türkiye

${ }^{2}$ Ondokuz Mayıs Üniversitesi, Tıp Fakültesi, Tıbbi Biyokimya Anabilim Dalı, Samsun, Türkiye

Zeynep UZDiL, Arş. Gör. Nermin KILIÇ, Prof. Dr. Aliye ÖZENOĞLU, Doç. Dr.

\section{Iletişim: Zeynep Uzdil} Ondokuz Mayıs Üniversitesi, Sağlık Bilimleri Fakültesi, Beslenme ve Diyetetik Bölümü, Samsun, Türkiye Tel: +903623121919

E-Posta: zuzdil1010@hotmail.com

Gönderilme Tarihi : 04 Nisan 2019 Revizyon Tarihi ： 20 Ekim 2019 Kabul Tarihi : : 21 Ekim 2019

\section{ABSTRACT}

Objectives: The aim of this study was to investigate the effects of nutritional status and demographic characteristics on the hopelessness of university students.

Study Design: A cross-sectional study with a random sampling of students aged between 17-25 years, at Ondokuz Mayıs University was conducted. A questionnaire form investigating demographic characteristics and nutritional habits was applied to students. The food frequency questionnaire form and also the Beck Hopelessness Scale were used. Total scores range from $0-20$ points and are categorized according to symptom severity as follows: $0-3$ : normal; 4-8: mild; 9-14: moderate; 15-20: severe hopelessness. Statistical analysis of the data was evaluated with SPSS 21.0 statistical package program. $p<0.05$ was considered statistically significant.

Results: The mean hopelessness score of the students was $4.63 \pm 3.75$ and the mean of most of their hopelessness scores $(50.1 \%)$ was normal. Sleeping 5-6 hours and $\geq 10$ hours, smoking and using alcohol, using alcohol at least one time or more in a week were associated with a higher hopelessness score and skipping a meal was associated with a low hopelessness score $(p<0.05)$. Unhealthy foods such as processed meat product, fried vegetable, fried potato, soup (ready), peanut butter, candies, hamburger, ketchup, margarine, mayonnaise, chips were associated with higher hopelessness score when consumed frequently (daily or 5-6 times in a week) $(p<0.05)$.

Conclusion: The mean hopelessness score of university students who we examined was determined as normal. Sleeping time, smoking and alcohol use, frequent consumption of unhealthy foods had a relationship with the hopelessness scale.

Keywords: Demographic characteristic, hopelessness, nutrition, university student

Genç Yetişkinlerde Beslenme ile İlgili ve Demografik Hangi Özellikler Umutsuzluğu Etkiler: Türkiye' den Üniversite Öğrencilerinin Kesitsel Çalışması

ÖZET

Amaç: Bu çalışmanın amacı, beslenme durumu ve demografik özelliklerin üniversite öğrencilerinin umutsuzluğu üzerindeki etkilerini araştırmaktır.

Çalıșma Planı: Ondokuz Mayıs Üniversitesi' ne devam eden 17-25 yas arası öğrencilerin rast gele örnekleme yöntemiyle seçildiği kesitsel bir çalışmadır. Öğrencilere beslenme durumu ve demografik özellikleri sorgulayan bir anket formu uygulanmıștır. Besin tüketim sıklığı formu ve ayrıca Beck Umutsuzluk Ölçeği uygulanmıștı. Ölçeğin toplam skoru 0-20 puan arası değişmekte olup 0-3: normal, 4-8: hafif, 9-14: orta ve 15-20 puan ciddi umutsuzluğu ifade etmektedir. Verilerin istatistiksel analizi SPSS 21.0 istatistik paket programı ile değerlendirilmiştir. $p<0.05$ istatistiksel olarak anlamlı kabul edilmiştir.

Bulgular: Öğrencilerin umutsuzluk puanı ortalaması $4.63 \pm 3.75^{\prime}$ dir ve çoğunun umutsuzluğu (\%50.1) normaldir. Uyku süresi 5-6 saat ve $>10$ saat olan, sigara ve alkol kullanan, bir haftada en az bir sefer veya daha fazla alkol kullananların umutsuzluğu yüksek iken, öğün atlayanların umutsuzluk puanı düşüktür $(p<0.05)$. İ̧̧lenmiş et ürünü, kızarmış sebze, patates kızartması, çorba (hazır), yer fistığı, şeker, hamburger, ketçap, margarin, mayonez, cips gibi sağlıklı olmayan besinlerin sık (her gün veya haftada 5-6 sefer) tüketimi artmış umutsuzluk puanı ile ilişkilidir $(p<0.05)$.

Sonuç: Bu çalışmada araştırdığımız üniversite öğrencilerinin umutsuzluk puanı normal aralıkta belirlenmiştir. Uyku süresi, sigara ve alkol kullanımı ile sağlıkı olmayan besinlerin sık tüketimi umutsuzluk ile ilişkilidir.

Anahtar sözcükler: Demografik özellik, beslenme, umutsuzluk, üniversite öğrencisi 
B ased on studies on depressed patients, hopelessness is defined as not making an effort to reach a goal and expecting negative results about it even though it isnot based on a realistic reason (1). University period, mediate step from puberty to adulthood, is known as the end of puberty and beginning of adulthood and defined as the late period of puberty (2). University is different from other courses because students are trained to be professionals there and for this reason, they have positive expectations about the future.

Studies in Turkey show that youths and university students have a tendency to hopelessness $(3,4)$. Among various studies in Turkey about university students, mild to moderate hopelessness was determined $(5,6)$. Studies on university students showed that demographic characteristics such as gender, education level and working status of parents, departments of education, income rate and living place associated with the level of hopelessness $(2-4,7)$. In a study, having moderate or severe hopelessness rate was determined $13.9 \%$ of university students(8). Hopelessness is known to accompany many psychiatric disorders (9-11). It has shown that hopelessness can cause serious problems up to the suicide attempt among persons who have mental disorders especially depression and anxiety $(12,13)$. Besides, it is known that the presence of high hope influences academic success positively (14).

The influence of nutrients and some components on psychiatric disorders in the diet has been the subject of research in recent years. Especially vitamin C, beta-carotene and omega-3 fatty acids have been shown to have a positive effect on depressive symptoms (15-17). The decrease in fish consumption was found to be a risk for depressive disorders in males (18). It was shown that as the consumption of meat and vegetables increased, the rate of depression decreased (19). The Mediterranean diet that rich in vegetables, fruits, whole grains is determined to be effective in improving the mood according to a normal diet (20).In the literature research, there are not enough studies showing the relationship between nutritional status and hopelessness.

Hopelessness, also having negative expectations about the future for a person, adversely may affect to deal with problems and relationships with the environment. It is thought that improving nutritional status can affect not only the quality of life but also the contribution of mental and spiritual health. Because of that studies on nutritional status and hopelessness are insufficient, this study aimed to evaluate the effect of nutritional and demographic characteristics on the hopelessness of university students.

\section{Materials and Methods}

Study participants/sample

This is a cross-sectional study that a total of 733 students (age between 17-25 years) of Ondokuz Mayıs University who have an undergraduate education in four years program participated by random sampling method. University students who received four-year undergraduate education, who did not have perception disorders or communication problems and answered both the questionnaire and the scale completely were included in the study.

\section{Procedure of investigation}

A questionnaire form that contains; demographic characteristics, nutritional status, lifestyle of students and a scale (Beck Hopelessness Scale-BHS) which determines the hopelessness level of students, was applied to the students. The scale which was developed by Beck et al in 1974, includes 20 true-false items and it is a self-assessment scale. Total scores range from 0-20 points and as the scale score increases, the level of hopelessness increases. The scale is categorized according to symptom severity as follows: 0-3: normal; 4-8: mild; 9-14: moderate; 15-20: severe $(21,22)$.

To determine the nutritional status; a food frequency questionnaire that contains 56 foods in total, was applied and the evaluation was dependent on two conditions which are frequent consumption (daily or 5-6 times in a week) and rare consumption (1 time in 15 days or less). Body mass index (BMI) was used to evaluate body weight and the BMI was classified according to World Health Organization criteria.

\section{Statistical analysis}

The statistical analyses were performed with Statistical Package for Social Sciences version 21.0 for Windows. The results were presented as percentages, means \pm standard deviation, median (minimum-maximum). Pearson's chisquared test was used to determine the habits of students according to sex. For comparison, two non-parametric independent groups, Mann-Whitney $U$ test was used; for more than two non-parametric independent groups, Kruskal-Wallis test was used. Pearson's correlation was used to determine the relationship with hopelessness. $\mathrm{p}<0.05$ was considered statistically significant. 
This study was carried out according to ethical principles and the ethical permission was taken from "Ethics Committee of Clinical Research of Ondokuz Mayıs University" and issue number is B.30.2.ODM.0.20.08/2112. It is derived from the master thesis of Zeynep Uzdil and the name was "The relationship between hopelessness level with nutritional status and demographic characteristics in university students".

\section{Results}

A total of 733 university students, 353 (48.2\%) men and 380 (51.8\%) women were included in the study. As shown in Table 1, the habit of smoking and alcohol use for men was $40.8 \%(n=144)$ and $44.8 \%(n=158)$, respectively. Also, the smoking and alcohol habits of men were higher than women $(p<0.001)$. Hopelessness status according to the sex was not different $(p>0.05)$.
The mean BMl of men and women were $23.34 \pm 3.39 \mathrm{~kg} /$ $\mathrm{m}^{2}$ and $21.41 \pm 3.13 \mathrm{~kg} / \mathrm{m}^{2}$ respectively and higher for men $(p<0.001)$. According to the classification of BMI, $70.0 \%$ of the students were normal and $20.1 \%$ of them were obese (Not given in the table). The mean hopelessness score of students was $4.63 \pm 3.75$ points. According to the classification of hopelessness score, $50.1 \%$ of them were normal hopelessness (Table 1).

$72.2 \%$ of students watch television and $88.5 \%$ of them use tablet/computer. There was a positive correlation between hopelessness score and the duration of watching television and using tablet/computer $(r=0.152$ and $r=0.220$, respectively) (Not given in the table).

\begin{tabular}{|c|c|c|c|}
\hline Variables & Men $(\mathrm{N}=353)$ & Women $(\mathrm{N}=380)$ & Total $(\mathrm{N}=733)$ \\
\hline \multicolumn{4}{|l|}{ Health status } \\
\hline Non-healthy & $26(7.4)$ & $57(15.0)$ & $83(11.3)$ \\
\hline Healthy & $327(92.6)$ & $323(85.0)^{* *}$ & $650(88.7)$ \\
\hline \multicolumn{4}{|l|}{ Smoking habit } \\
\hline Smoker & $144(40.8)^{*}$ & $48(12.6)$ & $192(26.2)$ \\
\hline Non-smoker & 209(59.2) & $332(87.4)$ & $541(73.8)$ \\
\hline \multicolumn{4}{|c|}{ Alcohol consumption habit } \\
\hline Yes & $158(44.8)^{*}$ & 102(26.8) & $260(35.5)$ \\
\hline No & $195(55.2)$ & $278(73.2)$ & $473(64.5)$ \\
\hline \multicolumn{4}{|l|}{ Exercise status } \\
\hline Regular & $157(44.5)^{*}$ & $66(17.4)$ & $223(30.4)$ \\
\hline Never & 196(55.5) & $314(82.6)$ & $510(69.6)$ \\
\hline \multicolumn{4}{|l|}{ Hopelessness status } \\
\hline Normal & $167(47.3)$ & $200(52.6)$ & $367(50.1)$ \\
\hline Mild & $114(32.3)$ & $119(31.3)$ & $233(31.8)$ \\
\hline Moderate & $68(19.3)$ & $56(14.7)$ & 124(16.9) \\
\hline Severe & $4(1.1)$ & $5(1.3)$ & $9(1.2)$ \\
\hline \multicolumn{4}{|l|}{ Skipping meals status } \\
\hline Yes & $164(46.5)$ & $201(52.9)$ & $365(49.8)$ \\
\hline No & 63(17.8) & $47(12.4)$ & $110(15.0)$ \\
\hline Sometimes & $126(35.7)$ & $132(34.7)$ & $258(35.2)$ \\
\hline BMI $\left(\mathrm{kg} / \mathrm{m}^{2}\right)$ & $23.34 \pm 3.39^{*}$ & $21.41 \pm 3.13$ & $22.34 \pm 3.40$ \\
\hline Hopelessness score & $4.89 \pm 3.85$ & $4.39 \pm 3.63$ & $4.63 \pm 3.75$ \\
\hline
\end{tabular}




\begin{tabular}{|c|c|c|c|c|c|c|}
\hline \multirow[b]{2}{*}{ Variables } & \multicolumn{2}{|c|}{ Men } & \multicolumn{2}{|c|}{ Women } & \multicolumn{2}{|c|}{ Total } \\
\hline & $\begin{array}{l}\text { Median (min-max)/ } \\
\text { Mean rank }\end{array}$ & Test statistics & $\begin{array}{l}\text { Median (min-max)/ } \\
\text { Mean rank }\end{array}$ & Test statistics & $\begin{array}{l}\text { Median (min-max)/ } \\
\text { Mean rank }\end{array}$ & Test statistics \\
\hline Exercise & & $\mathrm{U}=14356$ & & $U=9979$ & & $\mathrm{U}=5541$ \\
\hline Yes & \multicolumn{2}{|l|}{$4(0-19) / 183.88$} & \multicolumn{2}{|l|}{$4(0-14) / 196.30$} & \multicolumn{2}{|l|}{$4(0-19) / 386.39$} \\
\hline No & \multicolumn{2}{|l|}{$3.5(0-19) / 171.49$} & \multicolumn{2}{|l|}{$3(0-17) / 189.28$} & \multicolumn{2}{|l|}{$3(0-19) / 358.52$} \\
\hline Alcohol use & & $U=13876$ & & $U=12523$ & & $U=54141$ \\
\hline Yes & \multicolumn{2}{|l|}{$4(0-19) / 186.74$} & \multicolumn{2}{|l|}{$4(0-17) / 206.73$} & \multicolumn{2}{|l|}{$4(0-19) / 395.27^{*}$} \\
\hline No & \multicolumn{2}{|l|}{$3(0-19) / 169.11$} & \multicolumn{2}{|l|}{$3(0-17) / 184.55$} & \multicolumn{2}{|l|}{$3(0-19) / 351.46$} \\
\hline Smoking & & $U=13596$ & & $U=6286$ & & $U=44308$ \\
\hline Yes & \multicolumn{2}{|l|}{$4(0-19) / 187.08$} & \multicolumn{2}{|l|}{$4(1-17) / 225.54^{*}$} & \multicolumn{2}{|l|}{$4(0-19) / 406.73^{*}$} \\
\hline No & \multicolumn{2}{|l|}{$3(0-19) / 170.06$} & \multicolumn{2}{|l|}{$3(0-17) / 185.43$} & \multicolumn{2}{|l|}{$3(0-19) / 352.90$} \\
\hline Duration of smoking (year) & & $x^{2}=0.115$ & & $x^{2}=5.424$ & & $x^{2}=0.743$ \\
\hline $0-3$ & \multicolumn{2}{|l|}{$4(0-15)$} & \multicolumn{2}{|l|}{$3(1-10)$} & \multicolumn{2}{|l|}{$4(0-15)$} \\
\hline $4-6$ & \multicolumn{2}{|l|}{$4(0-17)$} & \multicolumn{2}{|l|}{$6(1-17)$} & \multicolumn{2}{|l|}{$5(0-17)$} \\
\hline$\geq 7$ & \multicolumn{2}{|l|}{$5(0-19)$} & \multicolumn{2}{|l|}{$5(2-14)$} & $5(0-19)$ & \\
\hline Alcohol consumption frequency & & $x^{2}=20.631^{*}$ & & $x^{2}=12.694^{* *}$ & & $x^{2}=33.655^{*}$ \\
\hline At least once a week or more often & $6(0-19) a$ & & $7(0-17) a$ & & $6(0-19) a$ & \\
\hline Once or twice a month & $3(1-14) b$ & & $3(0-15) b$ & & $3(0-15) b$ & \\
\hline Less than once a month & $2(1-17) b$ & & $2(0-11) b$ & & $2(0-17) b$ & \\
\hline Sleep duration (hour) & & $x^{2}=6.048^{* *}$ & & $x^{2}=8.672^{* *}$ & & $x^{2}=15.137^{*}$ \\
\hline $5-6$ & $4(0-19) a b$ & & $4(0-15) a$ & & $4(0-19) a$ & \\
\hline $7-8$ & $3(0-14) a$ & & $3(0-16) b$ & & $3(0-16) b$ & \\
\hline$\geq 10$ & $4.5(0-19) b$ & & $4(0-17) b$ & & $4(0-19) a b$ & \\
\hline BMI classification & & $x^{2}=1.108$ & & $x^{2}=7.501$ & & $x^{2}=5.475$ \\
\hline Underweight & $3.5(1-17)$ & & $3(0-10)$ & & $3(0-17)$ & \\
\hline Healthy weight/Normal & $4(0-19)$ & & $3(0-17)$ & & $3(0-19)$ & \\
\hline Overweight & $4(0-14)$ & & $3(0-14)$ & & $4(0-14)$ & \\
\hline Obese & $4(1-12)$ & & $6(4-10)$ & & $5(1-12)$ & \\
\hline Skipping meals status & & $x^{2}=13.182^{* *}$ & & $x^{2}=9.205^{* *}$ & & $x^{2}=21.447^{*}$ \\
\hline Yes & $4(0-19) a$ & & $4(0-16) a$ & & $4(0-19) a$ & \\
\hline No & $6(0-14) b$ & & $5(0-17) a$ & & $5.5(0-17) \mathrm{b}$ & \\
\hline Sometimes & $3(0-12) a$ & & $3(0-17) b$ & & $3(0-17) c$ & \\
\hline
\end{tabular}

In Table 2, the distribution of hopelessness score according to sex was given. Students who are smoking and using alcohol had higher hopelessness scores than others $(p<0.001)$ and also women who are smoking had higher hopelessness scores $(p<0.001)$, but among men, smoking was not significantly important for hopelessness ( $p>0.05)$. Hopelessness score was significantly higher in those with a high frequency of alcohol use among all students $(p<0.001)$ and also for men and women $(p<0.001$ and $p<0.05$, respectively). Although hopelessness score was not statistically significant for the prolonged smoking duration $(p>0.05)$. Hopelessness score was significantly higher for students who sleep 5-6 hours than 7-8 hour
( $p<0.001)$, for men sleeping $\geq 10$ hours was higher than 7-8 hours $(p<0.05)$.

As shown in Table 2, students who skip meals and sometimes skip meals had lower hopelessness score than not skipping $(p<0.001)$. For men and women, not skipping meals was related to higher hopelessness $(p<0.05)$. According to the BMI classification, hopelessness was not statistically different for men and women ( $p>0.05)$.

The food consumption frequency and distributions of hopelessness score according to the frequency of consumption are given in Table 3. Students who consume white cheese, yogurt with fruit, processed meat product, fried 
potato, fried vegetable, toast/sandwich, hamburger, bagel, patty/pizza, cakes/cookies, soup (ready), margarine, mayonnaise, candies, peanutbutter, chips, ketchup/salad sauce, frequently had higher hopelessness score $(p<0.05)$.
In several studies, mean hopelessness scores of university students were determined $4.56 \pm 3.42 ; 4.40 \pm 4.03$; $4.22 \pm 4.33$ and $6.06 \pm 4.80$ points, respectively $(8,23-25)$. In another study, hopelessness score of individuals who are $17-25$ years old was determined $5.56 \pm 4.35$ points (26).

Table 3. Distributions of hopelessness score according to the frequency of food consumption

\begin{tabular}{|c|c|c|c|c|c|c|c|c|}
\hline \multirow[t]{2}{*}{ Foods } & \multicolumn{3}{|c|}{ Frequent consume } & \multicolumn{3}{|c|}{ Rare consume } & \multirow{2}{*}{ U } & \multirow{2}{*}{$p^{\prime}$} \\
\hline & $\%$ & $\begin{array}{c}\text { Median } \\
(\text { min-max })\end{array}$ & Mean rank & $\%$ & $\begin{array}{c}\text { Median } \\
(\text { min-max })\end{array}$ & Mean rank & & \\
\hline \multicolumn{9}{|l|}{ Dairy products } \\
\hline White cheese & 67.40 & $3(0-19)$ & 350.85 & 32.60 & $4(0-19)$ & 400.39 & 67.012 & 0.003 \\
\hline Yoghurt with fruit & 30.60 & $4(0-15)$ & 398.54 & 69.40 & $3(0-19)$ & 353.12 & 49.943 & 0.007 \\
\hline \multicolumn{9}{|l|}{ Meat products } \\
\hline Processed meat product & 43.00 & $4(0-14)$ & 386.73 & 57.00 & $3(0-19)$ & 352.13 & 59621 & 0.028 \\
\hline \multicolumn{9}{|l|}{ Vegetables } \\
\hline Fried potato & 47.30 & $4(0-19)$ & 387.85 & 52.70 & $3(0-19)$ & 348.25 & 59.735 & 0.011 \\
\hline Fried vegetable & 45.20 & $4(0-17)$ & 392.79 & 54.80 & $3(0-19)$ & 345.76 & 57.993 & 0.003 \\
\hline \multicolumn{9}{|l|}{ Grains } \\
\hline Toast, sandwich & 48.80 & $4(0-19)$ & 390.48 & 51.20 & $3(0-17)$ & 344.58 & 58.718 & 0.003 \\
\hline Hamburger & 36.40 & $4(0-19)$ & 419.49 & 63.30 & $3(0-19)$ & 336.93 & 48.197 & $<0.001$ \\
\hline Bagel & 49.40 & $4(0-19)$ & 383.27 & 50.60 & $3(0-19)$ & 351.13 & 61.261 & 0.039 \\
\hline Patty, pizza & 37.10 & $4(0-19)$ & 417.01 & 62.90 & $3(0-19)$ & 337.49 & 49.094 & $<0.001$ \\
\hline Cake, cookie & 48.80 & $4(0-19)$ & 383.09 & 51.20 & $3(0-19)$ & 351.64 & 61.363 & 0.043 \\
\hline Soup (ready) & 30.00 & $4(0-17)$ & 409.18 & 70.00 & $3(0-19)$ & 348.91 & 47.150 & $<0.001$ \\
\hline \multicolumn{9}{|c|}{ Other foods (fatty, sweetened) } \\
\hline Margarine & 32.20 & $4(0-16)$ & 414.17 & 67.80 & $3(0-19)$ & 344.60 & 47.515 & $<0.001$ \\
\hline Mayonnaise & 35.20 & $4(0-19)$ & 405.16 & 64.80 & $3(0-19)$ & 346.27 & 51.430 & $<0.001$ \\
\hline Candies & 36.40 & $4(0-19)$ & 403.52 & 63.60 & $3(0-19)$ & 346.08 & 52.460 & $<0.001$ \\
\hline Peanut butter & 34.70 & $4(0-19)$ & 402.20 & 35.30 & $3(0-19)$ & 348.33 & 51.891 & $<0.001$ \\
\hline Chips & 39.40 & $4(0-19)$ & 400.93 & 60.60 & $3(0-19)$ & 344.91 & 54.352 & $<0.001$ \\
\hline Ketchup, salad sauce & 37.50 & $4(0-19)$ & 392.77 & 62.50 & $3(0-19)$ & 351.53 & 55.889 & 0.010 \\
\hline
\end{tabular}

\section{Discussion}

In this study, to determine the factors affecting hopelessness, a weak relationship was determined between the duration of watching television and using tablet/computer and also the level of hopelessness of those who spend time with electronic devices has increased. This can be attributed to the fact that with the developing technology, youngers can spend more time with technological devices such as television and tablet/computer and spendless time on the human relationship/interpersonalrelationship so as a result of this they may become increasingly unhappy individuals.

In this study, the mean hopelessness score of students was $4.63 \pm 3.75$ points.
The hopelessness score of American university students was determined $4.36 \pm 4.58$ points(12).

In this study, the rates of smoking and using alcohol were $26.2 \%(n=192)$ and $35.5 \%(n=260)$ respectively. In another study, the rates of smoking and using alcohol of university students were $22.5 \%$ and $\% 18.0$, respectively(27). In another study, the smoking rate was determined among $15.0 \%$ of students (28). The alcohol use among university students was $48.8 \%$ in Turkey and $25.8 \%$ of them use alcohol once a week (29). In this study, it was determined that using alcohol at least one or more times in a week was common. And also the hopelessness score of students who are smoking and using alcohol was higher than the others in this study. 
Besides, as the frequency of using alcohol increases, the average score of hopelessness increases $(p<0.05)$. This might be due to the fact that those people who have higher hopelessness are more likely to smoke and use alcohol because of their mood changes; and studies on people who have a diagnosis of alcohol dependence have shown that dependency recognition is related to hopelessness $(30,31)$.

The recommended duration of daily sleeping for healthy adults by the National Heart, Vascular and Blood Institute is 7-8 hours(32). In this study, it was determined that $55.9 \%$ of students slept as much as the recommended level. In a study, duration of 8 hours and less sleeping rate was determined $65.6 \%$ among university students(27). In another study, theduration of sleeping of $55.0 \%$ of the students was determined 7-8 hours(33). In this study, sleep duration and hopelessness were associated and sleeping below and above 7-8 hours were found to have a higher BHS score. From these results, we think that sleeping less than the recommended level causes not to get enough rest for the body and too much sleep will cause most of the daily activity to go to sleep, so these situations can change the mood.

In this study, we determined that $49.8 \%$ of students skip meals. In another study, $63.8 \%$ of students skip meals and especially $54.5 \%$ of them skip breakfast (34). In this study, the hopelessness score of students who are skipping meals statistically determined to be lower than those who are not skipping meals $(p<0.05)$. These situations may be related to the changes in the emotional state, and the presence of hopelessness could be the leading cause for the students to eat, and so they don't skip meals there by consuming frequent meals.

We determined that when white cheese was rarely consumed, the hopelessness scores of students were high. In a study, inadequate intake of calcium; which the most common mineral in milk and dairy products, has been associated with depressive symptoms (16). We determined that students who frequently consume processed meat products which in the meat group their hopelessness score was higher. Meat is the main protein source of the diet; however, it is known that protein consumption diminished depressive symptoms and choosing a meat group from healthy foods will have positive effects on hopelessness (35). We expected that vegetable consumption inversely related to hopelessness. In this group,we determined that those who frequently consumed fried vegetables and fried potato has a higher hopelessness score. Especially in Turkey, the oil used for frying is often sunflower oil which is rich in n-6 fatty acids. In a study, it is shown that consuming linoleic acid increases depression that often accompanied by hopelessness(36).

The great majority of carbohydrates, which are the main energy source of the diet,are provided from bread and cereals. We determined that those who frequently consumed toast/sandwich, hamburger, bagel, patty/pizza, cake/cookie had a higher hopelessness score. When these foods being in a diet frequently and consumed in excess they may cause an increase in body weight due to higher energy intake. Also, determining the amount of consumption of these foods and their association withhopelessness will be beneficial. Students who frequently consume margarine, mayonnaise, peanut butter, candies had higher hopelessness scores. Foods in this group have high energy and people who like and frequently consume them will increase their energy intake. Increased energy intake can cause obesity and chronic diseases and thus developing health problems due to nutrition which can cause hopelessness. Foods such as toast, bagel, cream, peanut butter and candies are ready to eat so students who have high hopelessness scores could prefer to consume these foods. In this group, consuming foods that are poor in protein, vitamins and minerals can explain their relationship with hopelessness; also who consume mayonnaise, hamburger, chips and ketchup/salad sauces frequently had higher hopelessness score which is the reason that these foods are not suggested in a healthy diet.

\section{Conclusion}

At the end of this study; the duration of sleeping, watching television and using a tablet/computer had a relationship with hopelessness. The relationship between sleeping duration and hopelessness can influence the food consumption of students so it is important for students to have adequate sleep. Smoking and alcohol use were related to hopelessness. Foods that are not recommended to be consumed in a healthy diet are found to increase hopelessness score and it is important that individuals practice healthy eating behaviors recommended by specialists. In order to easily consume the foods in the milk, meat, vegetable and fruit groups by university students, it is necessary to be easily accessible in the university canteens, cafeterias and where students hosted. Efforts to reduce the factors contributing positively to the hopelessness of the youngers can also make a significant contribution to community health. There is a need for state policies that 
support the level of education and the economic situation so that society can achieve its lifestyle and nutrition goals. Thus, it is thought that individuals will be able to look more positively for the future and minimize hopelessness.

\section{References}

1.Seber G, Dilbaz N, Kaptanoğlu C et al. Umutsuzluk Ölçeği: Geçerlilik ve Güvenirliği. Kriz Dergisi. 1993;1:139-142.

2.Şahin C. Eğitim Fakültesinde Öğrenim Gören Öğrencilerin Umutsuzluk Düzeyleri. Selçuk Üniversitesi Ahmet Keleşoğlu Eğitim Fakültesi Dergisi. 2009;27:271-286.

3.Çam Çelikel F, Erkorkmaz U. Üniversite Öğrencilerinde Depresif Belirtiler ve Umutsuzluk Düzeyleri ile İlişkili Etmenler. Archives of Neuropsychiatry. 2008;45:122-129.

4.Özmen $D$, Erbay Dündar $P$, Çetinkaya $A C ̧$, et al. Lise öğrencilerinde umutsuzluk ve umutsuzluk düzeyini etkileyen etkenler. Anadolu Psikiyatri Dergisi. 2008;9:8-15.

5.Özmen M, Coşman Ö, Kökcü A. Meslek Yüksekokulu öğrencilerinin umutsuzluk düzeyleri. International Journal of Social Sciences and Education Research. 2016;2:510-521.

6.Nas K, Sivrikaya AH. Spor Yapan ve Yapmayan Üniversite Öğrencilerinin Umutsuzluk Düzeylerinin Belirlenmesi. Journal of International Social Research. 2018;11:786-793.

7.Ehtiyar R, Üngüren E. Lise ve Üniversitede Turizm Eğitim Alan Öğrencilerin Demografik Değişkenlerinin Umutsuzluk ve Kaygı Düzeylerine Etkilerinin Araştırılması. Ticaret ve Turizm Eğitim Fakültesi Dergisi. 2008;2:34-51.

8.Poch FV, Villar E, Caparros B et al. Feelings of hopelessness in a Spanish university population. Social psychiatry and psychiatric epidemiology. 2004;39:326-334.

9.Valtonen HM, Suominen K, Haukka J et al. Differences in incidence of suicide attempts during phases of bipolar I and II disorders. Bipolar disorders. 2008;10:588-596.

10. Acosta FJ, Vega D, Torralba $L$ et al. Hopelessness and suicidal risk in bipolar disorder. A study in clinically nonsyndromal patients. Comprehensive psychiatry. 2012;53:1103-1109.

11. Pompili $M$, Innamorati $M, G o n d a ~ X$ et al.Affective temperaments and hopelessness as predictors of health and social functioning in mood disorder patients: a prospective follow-up study. Journal of affective disorders 2013;150:216-222.

12. Polanco-Roman L, Miranda R. Culturally related stress, hopelessness, and vulnerability to depressive symptoms and suicidal ideation in emerging adulthood. Behavior therapy. 2013;44:75-87.

13. Wang $\mathrm{Y}-\mathrm{y}$, Jiang $\mathrm{N}-\mathrm{z}$, Cheung EF et al. Role of depression severity and impulsivity in the relationship between hopelessness and suicidal ideation in patients with major depressive disorder. Journal of affective disorders. 2015;183:83-89.

14. Chang EC. Hope, problem-solving ability, and coping in a college student population: Some implications for theory and practice. Journal of clinical psychology. 1998;54:953-962.

15. Oishi J, Doi H, Kawakami N. Nutrition and depressive symptoms in community-dwelling elderly persons in Japan. Acta medica Okayama. 2009;63:9-17.

16. Miki T, Kochi T, Eguchi $M$ et al.Dietary intake of minerals in relation to depressive symptoms in Japanese employees: the Furukawa Nutrition and Health Study. Nutrition. 2015;31:686-690.

17. Rondanelli $M$, Giacosa $A$, Opizzi A et al.Effect of omega- 3 fatty acids supplementation on depressive symptoms and on health-related quality of life in the treatment of elderly women with depression: a double-blind, placebo-controlled, randomized clinical trial. Journal of the American College of Nutrition. 2010;29:55-64.
18. Li Y, Dai Q, Ekperi LI et al. Fish consumption and severely depressed mood, findings from the first national nutrition follow-up study. Psychiatry Research. 2011;190:103-109.

19. Meyer BJ, Kolanu N, Griffiths DA et al. Food groups and fatty acids associated with self-reported depression: an analysis from the Australian National Nutrition and Health Surveys. Nutrition. 2013;29:1042-1047.

20. Lee J, Pase M, Pipingas A et al.Switching to a 10-day Mediterraneanstyle diet improves mood and cardiovascular function in a controlled crossover study. Nutrition. 2015;31:647-652.

21. Ceyhan AA. Ortaöğretim alan öğretmenliği tezsiz yüksek lisans programına devam eden öğretmen adaylarının umutsuzluk düzeylerinin incelenmesi. Anadolu Üniversitesi Sosyal Bilimler Dergisi. 2004:91-102.

22. Yalçın S, Açıkgöz İ. Sağlık Bilimleri Fakültesi Son Sınıf Öğrencilerinin Umutsuzluk Düzeylerinin Karşılaștırılması/Comparison of The Hopelessness Levels Among The Fourth Grade Students At Faculty Of Health Science. Mustafa Kemal Üniversitesi Sosyal Bilimler Enstitüsü Dergisi. 2014;11:259-270.

23. Bayrami M, Heshmati R, Ghotbi $M$ et al. Relationship between personality dimensions and hopelessness: a study on college students. Procedia-Social and Behavioral Sciences. 2012;46:848-852.

24. Gençöz F, Vatan S, Walker RL et al. Hopelessness and suicidality in Turkish and American respondents. OMEGA-Journal of death and dying. 2007;55:311-319.

25. Zeyrek EY, Gençöz F, Bergman Y et al. Suicidality, problem-solving skills, attachment style, and hopelessness in Turkish students. Death studies. 2009;33:815-827.

26. Tercanlı N, Demir V. The Assesment of Beck Hopelessness Scale in Terms of Several Variables (The Sample of Gümüşhane Province) Gümüşhane Üniversitesi Sağlık Bilimleri Dergisi. 2012;1(1): 29-40.

27. Tavolacci MP, Grigioni S, Richard L et al. Eating disorders and associated health risks among university students. Journal of Nutrition Education and Behavior. 2015;47:412-420.

28. Evans-Polce R, Lanza S, Maggs J. Heterogeneity of alcohol, tobacco, and other substance use behaviors in US college students: A latent class analysis. Addictive Behaviors. 2016;53:80-85.

29. Akkaya S. Muğla Üniversitesi Öğrencilerinin Alkol Kullanma Sıklığının Araştıııması. Gümüşhane Üniversitesi Sağlık Bilimleri Dergisi. 2015;4:44-52.

30. Blume AW, Resor MR, Villanueva MR et al. Alcohol use and comorbid anxiety, traumatic stress, and hopelessness among Hispanics. Addictive Behaviors. 2009:34:709-713.

31. Zahra $P$, Khadigeh $D$, Mogtaba $Y$ et al. Study of the rate of Hopelessness and its associated factors in Youth of Yazd city, Iran. Procedia-Social and Behavioral Sciences. 2010;5:2108-2112.

32. Your Guide to Healthy Sleep National Heart, Lung and Blood Institute, 2011.

33. Pengpid S, Peltzer K. Prevalence of overweight/obesity and central obesity and its associated factors among a sample of university students in India. Obesity Research \& Clinical Practice. 2014;8:558-570

34. Ersoy N, Ayaz A. Üniversite Öğrencilerinin Kahvaltı Yapma Alışkanlıklarının Saptanması. Beslenme ve Diyet Dergisi. 2012;40:211-217.

35. Nanri A, Eguchi $M$, Kuwahara $K$ et al.Macronutrient intake and depressive symptoms among Japanese male workers: the Furukawa Nutrition and Health Study. Psychiatry Research. 2014;220:263-268.

36. Wolfe AR, Ogbonna EM, Lim S et al. Dietary linoleic and oleic fatty acids in relation to severe depressed mood: 10 years follow-up of a national cohort. Progress in Neuro-Psychopharmacology and Biological Psychiatry. 2009;33:972-977. 